\title{
PORTLAND CEMENT: THE NEED OF A STANDARD TEST.
}

By ERNEST R. MATrFHEWS, C.E., F.G.S., F.R.S.E. (MEIRER.)

ABSTRACT.

THE author has endeavoured in this paper to show that the time has arrived when there should be a standard cement test which every cement manufactured or used in this country should pass.

He states that the use of Portland cement for constructional purposes is a modern thing dating back only to about the year 1825, and that there never was a time when cement was so extensively used as to-day, especially does this apply to its use in all sanitary engineering works, such as sewers and reservoirs, neither was there ever a time when there were so many cements in the market, good and inferior, as the present time. In order to keep out the latter and prevent so many failures, it is, he maintains, most necessary that all cement should pass a standard test; as it is, the matter rests entirely with the engineer or architect, and what ont considers a fairly stringent cement test, another considers miserably weak; the specifications of some engineers and architects as to the quality and strength of cement are extremely weak, not only so, but in many specifications different clauses are altogether inconsistent and contradictory one with another, and so long as the manufacturer supplies lis cement in accordance with the specification, he cares nothing further; with many manufacturers the weaker the specification the more satisfactory to them. If a standard cement test were in vogrue, this use of inferior cement would be obviated.

The author finds that the ammual production of Portland cement in this country is about 24 per cent., or nearly one-fourth of the world's total output. Germany, however, outstrips every other country in cement manufacture, both as regards quality, quantity, and the realisation of the variety of uses to which cement (an be adapted. That country produces about 38 per cent., or more than one-third of the world's output. France comes next, with about 9 per cent.; the United States follow with about 8 per cent.; Belgium produces about 7 per cent., and Russia about 6 per cent. All other countries combined produce about 8 per cent. The total world's output of Portland cement to-day is about 40,000,000 barrels annually. 
The author says, "It seems almost incredible, but it is, nevertheless, a fact, that in this country where cement was first used, and has been and is so extensively used, unlike Germany, France, Russia, and several otler' countries, there is no stantard cement test."

The author then proceeds to show to what extent the specifications of engineers and architects differ as to the test necessary for the cement to pass. He shows that in sereral works of considerable magnitude recently completed, and designed by well-known engineers, the seven days' tensile strength test specified for neat cement was 350 lbs. per square inch: while he refers to other works where the seven days' neat ccment test per square inch was as much as $800 \mathrm{lbs}$. He then refers to others that were between these two extremes, viz., $400 \mathrm{lbs}$., $450 \mathrm{lbs}$, and $700 \mathrm{lbs}$. per' square inch respectively, and yet each of these works in which cement. was used were similar, some almost identically of the same kind.

He points out the fallacy of the old idea of considering that coment that went over $450 \mathrm{lbs}$. on the square inch was over-limed, and therefore not satisfactory.

He urges that a 28 days' test, as well as a seven days' test, is necessary in order to determine the regular increase of strength with acre, the latter. taken alone (as is the usual custom) he maintains is not a test at all, it is a complete fallacy to suppose that it is, and he most strongly recommends, as the most reliable test, a sand and cement test.

The author further maintains that a compression test is necessary; although seldom adopted, and points out how such a test may be made.

He then procents to describe what he considers the test should be as to weight, specific gravity, quickness in setting, fineness in grinding. soundness, and chemical analysis, and points out some of the popular fallacies concerning these tests.

He then concludes his paper by giving a summary of the specifications of nine well-known engineers and architects, which clearly shows how great a variation there is between them (no two of the specifications being exactly alike), and hou necessary it is that a stundard cement test should. be cidopted in this country.

He says: "It is extremely gratifying to know that the Institution of Civil Engineers, with the assistance of other institutions, has appointed an Engineering Standards Committee, which has for some little time past devoted much time and consideration to the standardization of various engineering materials, such as tram-rail sections, iron pipes, and other engineering materials. Portland cement, he lias no doubt, will at an early date receive their caref ul consideration. 